\title{
説苑 緎維製品の現状と將来のあり方
}

日東紡續 常務取締役甲斐 野市三 郎

\section{1.世界織維の動问について}

天然織維と，化学織維の発展経䋨を゙第1.表でながめる と，1955年の世界の全織維生産量は 273 檍 $\mathrm{lb}$ で前 2 年 とやや同水㴶化止まっている。
全蟣維の生産量中に占める割合を見ると，線に和いて 快 1951 年の $72 \%$ から每年減少し 1957 年汇 66\% まで低 下している. 羊毛は每年同水準を維持している。然緎 維の合計では 1951 年の82\%より1957 年の $77 \%$ と比較 してみると、ちようど5\%の減少を示している，人造緎

(第 1 表) 世界主要織維生花量（単位 100 万 lb)

\begin{tabular}{|c|c|c|c|c|c|c|c|c|c|}
\hline & 1951年 & 1952年 & 1953年 & 1954年 & 1955年 & 1956年 & 1957年 & 1958年 & 1959年 \\
\hline 綿 & $\begin{array}{r}16.691 \\
(72)\end{array}$ & $\begin{array}{r}17.184 \\
(73)\end{array}$ & $\begin{array}{r}18.496 \\
(72)\end{array}$ & $\begin{array}{r}18.527 \\
(71)\end{array}$ & $\begin{array}{r}18.921 \\
(69)\end{array}$ & $\begin{array}{r}18.574 \\
(68)\end{array}$ & $\begin{array}{r}17.957 \\
(66)\end{array}$ & & \\
\hline 毛 & $\begin{array}{r}2.357 \\
(10)\end{array}$ & $\begin{array}{r}2.549 \\
\text { (11) }\end{array}$ & $\begin{array}{c}2.565 \\
(10)\end{array}$ & $\begin{array}{c}2.615 \\
(10)\end{array}$ & $\begin{array}{c}2.742 \\
(10)\end{array}$ & $\begin{array}{c}2.870 \\
(10)\end{array}$ & $\begin{array}{r}2.920 \\
\text { (11) }\end{array}$ & & \\
\hline 絹 & 47 & 59 & 57 & 60 & 65 & 68 & 67 & & \\
\hline $\begin{array}{l}\text { レ゙ーシ } \\
\text { アセテート }\end{array}$ & $\begin{array}{c}3.992 \\
(17.1)\end{array}$ & $\begin{array}{r}3.517 \\
(14.9)\end{array}$ & $\begin{array}{r}4.121 \\
(16.1)\end{array}$ & $\begin{array}{r}4.470 \\
(17.1)\end{array}$ & $\begin{array}{r}5.009 \\
(18.3)\end{array}$ & $\begin{array}{c}5.238 \\
(19.1)\end{array}$ & $\begin{array}{r}5.436 \\
(19.9)\end{array}$ & & \\
\hline 合 & $\begin{array}{r}228 \\
(0.9)\end{array}$ & $\begin{array}{l}282 \\
(1.1)\end{array}$ & $\begin{array}{r}349 \\
(1.4)\end{array}$ & $\begin{array}{r}430 \\
(1.6)\end{array}$ & $\begin{array}{r}585 \\
(2.1)\end{array}$ & $\begin{array}{r}680 \\
(2.5)\end{array}$ & $\begin{array}{r}903 \\
(3.1)\end{array}$ & $\begin{array}{l}\text { (1.263) } \\
\text { 推 定 }\end{array}$ & $\begin{array}{c}\text { (1.756) } \\
\text { 推 定 }\end{array}$ \\
\hline 䚵 & $\begin{array}{r}23.315 \\
(100)\end{array}$ & $\begin{array}{r}23.591 \\
(100)\end{array}$ & $\begin{array}{r}25.588 \\
(100)\end{array}$ & $\begin{array}{c}26.102 \\
(100)\end{array}$ & $\begin{array}{r}27.322 \\
(100)\end{array}$ & $\begin{array}{r}27.430 \\
(100)\end{array}$ & $\begin{array}{r}27.283 \\
(100)\end{array}$ & & \\
\hline
\end{tabular}

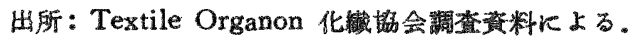

( )内はパーセント

(第 2 表) 米国主要 織維消素量（単位: 100 万 $\mathrm{lb}$ )

\begin{tabular}{|c|c|c|c|c|c|c|c|c|c|}
\hline & 1951年 & 1952年 & 1953年 & 1954年 & 1955年 & 1956年 & 1957年 & 1958年 & 1959年 \\
\hline 綿（消 瞽） & 5,300 & 4,600 & 4,700 & 4,300 & 4,400 & 4,600 & 4,300 & & \\
\hline 毛(洗上消踳) & 396 & 379 & 454 & 350 & 381 & 404 & 342 & & \\
\hline 絹（消 賴） & 6 & 6 & 5 & 6 & 7 & 7 & 5 & & \\
\hline 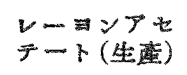 & 1,294 & 1,136 & 1,197 & 1,086 & 1,261 & 1,148 & 1,139 & $\begin{array}{l}(1,533) \\
\text { 推定 }\end{array}$ & $\begin{array}{l}(1,530) \\
\text { 推定 }\end{array}$ \\
\hline 合縕（生蔆） & 171 & 211 & 247 & 285 & 379 & 400 & 516 & $\begin{array}{l}\text { (696) } \\
\text { 推 定 }\end{array}$ & 推定 \\
\hline
\end{tabular}

出所: Textile Organon 織維年鑑Kよる

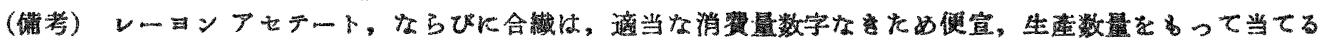

(第 3 表) 日本主要 緎 維消費 量 (単拉 100 万 lb)

\begin{tabular}{|c|c|c|c|c|c|c|c|c|c|}
\hline & 1951年 & 1952年 & 1953年 & 1954年 & 1955年 & 1956年 & 1957年 & 1958年 & 1959年 \\
\hline 線 （消 贊） & 900 & 1,000 & 1,200 & 1,100 & 1,200 & 1,400 & 1,250 & 1,010 & \\
\hline 毛(洗上消費) & 63 & 99 & 125 & 110 & 127 & 171 & 188 & & \\
\hline 絹 (消 責) & 17 & 23 & 22 & 21 & 24 & 28 & 28 & & \\
\hline 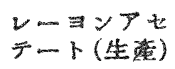 & 369 & 404 & 521 & 633 & 732 & 917 & 967 & 720 & \\
\hline 合織 (生崖) & 7 & 8 & 14 & 21 & 35 & 64 & 94 & 102 & 推定 \\
\hline
\end{tabular}

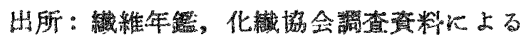

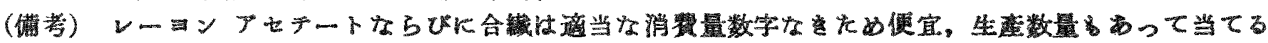


維はこの間 $5 \%$ の上界索㴚げた訳である。1957年には 前年 $21.6 \%$ から $23 \%$ 飞增光ている。このうちレーヨン アセテートは $19.9 \%$ ，合成絨維は $3.1 \%$ を占めている。

1951年を基準にして各織維の発展経撑を生産指数をと ってながめて見ると、第2図のごとく編，毛，絹の生産 は汪注各年共同一水準であるのに比しどスンース,フ セデート瀻維に打いては 1957 年は 1951 年の約1.4倍に

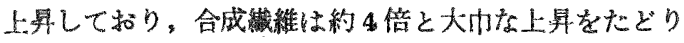
1958年には約 6 倍, 1959年には䄪 8 倍と大巾な增産が予 想されている。

以上世界の緎維生産の推移と併行して第 2 表お゙よび第

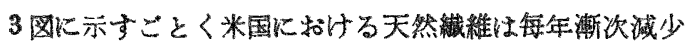
しており、これに比して化学䋘維特に合成瀻維の発展は 目喾しく世界第1位にある。本の主要織維生産量, 消

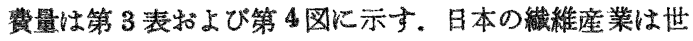

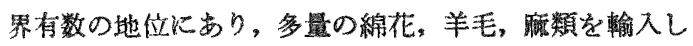
綿の消費は $5 ， 6$ 年前とあまり変らないが，羊毛におい

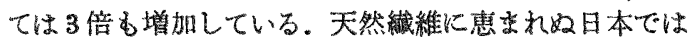
莫大な外貨を支払って翰入に依存しているが，消贊経佩 の進展に伴い,一方, 多量の化学織維を国庰一元を消鿓 して各種の織維媻品を製造し, 国内霹要を充たし, 輸出 の振興を計っている。

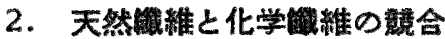

20世紀の科学の進步は原子力を始め䉓子技術，オ一ト メーション, 合成化学等目覚しいるのがある。化学䋘維 の普及むその一つに挙げなければならぬ.1892年ビスコ 一ス人絧系が発見されてから，60年余のわずかの間にレ ーシンステープル,フセテート,ナイロン,ビニロン等 の新载維がぞくぞく生産されると共に，との消費は急激 に增大した。前述のことく、いまや化学瀻維は量的に綿, 毛と並んで世界の3大主要瀻維となって蛒り，絹，毛は 絶対量飞招いては化学織維に追い拔かれて扣り，消費は 減少し始めている.日本の綿については朝鮮動乱後の不 況の中にあってたびたび操短を行い，生産の伸びが止っ ているに対し化学繊維はひたすら增應一途にたどってい ることである、今日すでに「緎維間の斗い」が開始され

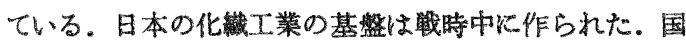
滻の線花を持たない日本の特殊性から自給自足の体制の 名の下で政府化倳の增産を奖励し，ひで世界大戦の 突入により綿花の榆入が現実に打切られ，化䋘の強制使 用が行なわれたのである。戦後の化織の発達はこの土台 の上に策き上げられた。最近線花は白由に輸入できる。 その中で化轼の露要が伸びてきたことはわれわれ消费者

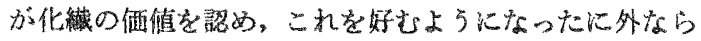
ない，それだけ化織の品質が向上したこととなる。化緇 は工場で生産され，綿は天然から持って生れたもので変

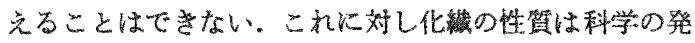
展に伴い人間の好みに応じていくらでも改質でき，価格 の点でも製造技術の発展により，大量生産でどしどし安 くなる可能性がある、一方は停滞し他方は進步する化瀻 がをすます倠展することは礁かである。綿は一眭の最盛 期を過ざ下降に向っている現状である。他方羊毛工業の

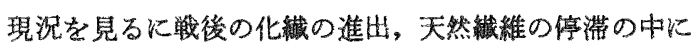
あって，羊毛工業は天然瀻維でありながら戦前をかずか に上回る発展を遂げている。これは戦後を通して国民衣 料生活に括いて洋服化の倾向が大きく作用しているこは ともちろん,ここ数年の消費の伸び虫大きく最近の繊維 消費の高級化が緎維の需要を高価ではあるが，繊維とし てもつ軽量, 保温性染色性等のよい性䝷をるつ羊毛淮 移せしめつつあることに起因するあのである．現在まで 化織仙よって代替されつつある天然瀻維は緗をはじめと し、綿、麻等であり，羊毛は情とんど影響を受けず,かえっ て麗要が伸びている，しかし今後羊毛代替となる各種合 成織維の生産により，羊毛工業はこれらとの関係の下で

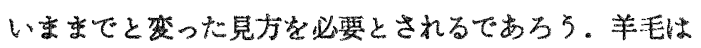
あらゆる蟣維の中で最もすぐれた性質をもっている。合 成絩維は強度等に执いて羊毛よりすぐれた性質を有する が，総合的に見て未だ羊毛を淩鴐するに到っていないし 価格も相当高い。しかし今日合成瀻維の生産技術の向上 によって,洒格、品質の雨面に㨟いて羊毛近迫すること は明らかであり，一般消独者に対する普及宣伝により今 後羊毛分野に合成緎維が急速に食边んでくることは明白 化予想されるところである，化学樴維がその形態におい

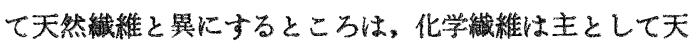
然資源の乏しい不自由な国で発達咕るもので，日本，イ タリー、ドイッ等では紡, 羊毛等天然紻維に恵まれず, その全部を輸入に依存せざるを得なかったため，七ルロ 一ズよりの䋊維により自国の財政を䝵っていた・これに 対し合成瀻維㹥石油，天然ガス，石炭，䉓力等の資源の 䇺富なアメリカイギリ大等に発展したもので, その点両 者の形態が変っている.フメリカは同国で繶がとれ、イ ギリスでは滖洲で十分羊毛がとれるという国で合成緇維 が発達した訳であるがこれは結局化学の発達化伴う自 然の結果とい光よう。現在の天然織維の不足を禣なうた め化学の生んだ新しい瀻維を相当生産しても十分事業化 して行けるということで准步したすのであろう。綿,毛， 絹等の天然瀻維は世界のどこの国です産出するという。 
のではない、日本の享请を思い出して見るとすぐ判る。 綿は見在日本ではまったく産出されず羊毛宗たしかりで ある、すなわら天然瀻維は国により有䵵があって多過ぎ たり少なすきたりすべて不公平であるが，化瀻はどこの 国です人間の知識二科学の発達によりどこでも生み出す ことができる。天然繊維の生噇には一定の限界がある。 綿花、桑、欐など裁培する崽や羊を飼有する上地を無限 に厷げることはでさないむしろ最近は狭められている。 このことは人口增加に伴って，食糧增湤住它確保等の十: 地の制約から生じて来るるのである。今までのよ5に天 然㵶維にすべてを依存することは将来期待されず，供給 の大部分は現在急激に発居している化学瀻維が担当せさ るを得ない運命にあると云い得る。天然䋘維扣よび化学 緎維の性質の大略は第 4 表に示す，各自特有の性質を生 かし単独であるいは個々の緎維のるつ欠点を他の繊維と

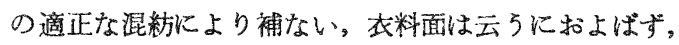
工業用に到る広い分野にわたり国家の経済に大い槣与 している. 次に主要緎維について簢篻に述べる。

（イ）編大臬瀻維として綿は強度，特湿強度高く

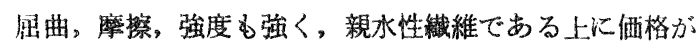
低廉であるため, 农料用として下着類，メリヤス製品， 靴下，服地，ワイシャツを始め各方面に，一力工業用とし てロープ,タイヤコード用原系, 沪部として広範な需要 分野を特っていることはいまさら言及するまですない。

（口）羊毛優れた保温性，伸曼弾性，易染性を特つ 羊毛は高級衣料分野に絶対的の地盤を確立している。最 近の原毛の值下りの傾向から見て現在発履途上儿ある種 々の合瀻は価格の面からのみならず品質自体の面に扣い て双方競合することとなろう。

（ハ）レーヨンステープル 染色性にすぐれ安仙な ため広く実用的农料として用いられている、レーヨンス テープルは織物は腰が弱く䏢になりやすく，縮みの多い 等の欠点があったがこれらは織物の樹脂加工により解消 されている、レーヨンステープルは綿と異なり，太さ， 長さ，光沢を自由に变光ることができ，京た羊毛のよ5 ならぢれと綿のようなねじれをるった巻鏥レーヨンス テープルがでさると，我料用はもらろん製造技術の改良 に伴い工業用緎維としても伸びつつある。

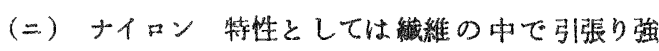

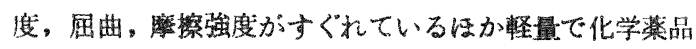
にす強く染色性す良く,衣料用，工業用に広く用いられて いる。またナイロンの加工媻品のーつをしてストレッチ ナイロン系は上記の特色下加人，羊毛風の感触，弹力 性, 保温性に笛み, 吸水性を生し，最近の需要は非常に 伸びている.1957 年の原系消費悬は 3500 4000万1b そ推定れさている。
（ホ）テトロン 引張り㤝度, 伸長弹性, 出曲強渡, 摩擦强度，酎薬品性がすぐれており，フィシィント系は 絹にステープルは毛に類侧して就り，合成瀻維としては 厇範な用途に適している。ステープルには混紡織物とし て特に綿混紡が大巾に伸びている。なかんずく綿，混ワ イシャツは wash and wear 織物分野の基盤筑いた。。

(へ）オーロン 人造羊毛として生廒された Du Pont のオーロンは比重が整く, 弾栍回復に富及, 屈曲, 摩摖 强㥰，染色性にすぐれている点で羊毛代替㵶維として登 場した。熱に対して強い収縮性を利用したパルキャ一 ンは outwear として今までの羊毛の占めていた地位を 㤪い去る急発展を示している。出界各国ではこの種のア クリル繊維が量産され、をさにアクリルラッシュの状 態を呈している.

\section{3. 合成緎維の琵紡についての考察}

特に急激な発展を伴 5 合成緎維との混紡の現状につい てふれることにする。一例をテトロンと綿あるいはレー ヨンステープルと混紡せる織物をとりあげると

1) 風合，反発性蓠性等織物の美的性䁈は良くなる。

2）嫂の回復はテトロン/綿=65\%/35\%は非常に優 秀であり，逆に綿75\%に增えると皱の回復は悪くなる。

3）プレスの保持性，洗だくの安定性はデトロン50\% までは優秀である。

4）引裂強度，摩擦強度はテトロン50\%をでは非常に ナぐれている。

以上の結果より Du. Pont社ではボリエスデル蟣維と 綿との最適混紡率を 65〜35\%としている。

以下に代表的な混絞製品の䧟正混紡率と織物の特性を 列記すると

混紡の種類潉紡率織物の持性

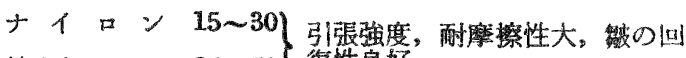
綿またはスフ 85〜70) 復性良好

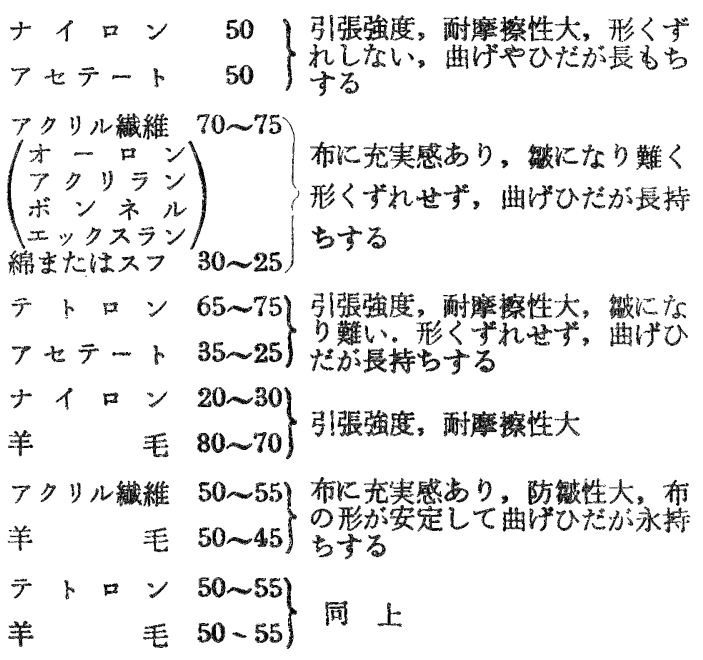




\begin{tabular}{|c|c|c|}
\hline アクリル縕維 & $70 \sim 75\}$ & \\
\hline ナイロン & $30 \sim 25\}$ & 防解性 \\
\hline フクリル維維 & 50 & 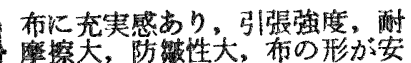 \\
\hline $\bar{T}+\square$ V & 50 & 整，曲げひた永特 \\
\hline $1 ロ ン$ & 50 & hot \\
\hline$卜 \square$ & 50 & \\
\hline
\end{tabular}

三種縉維の混䊉の場合をあげると

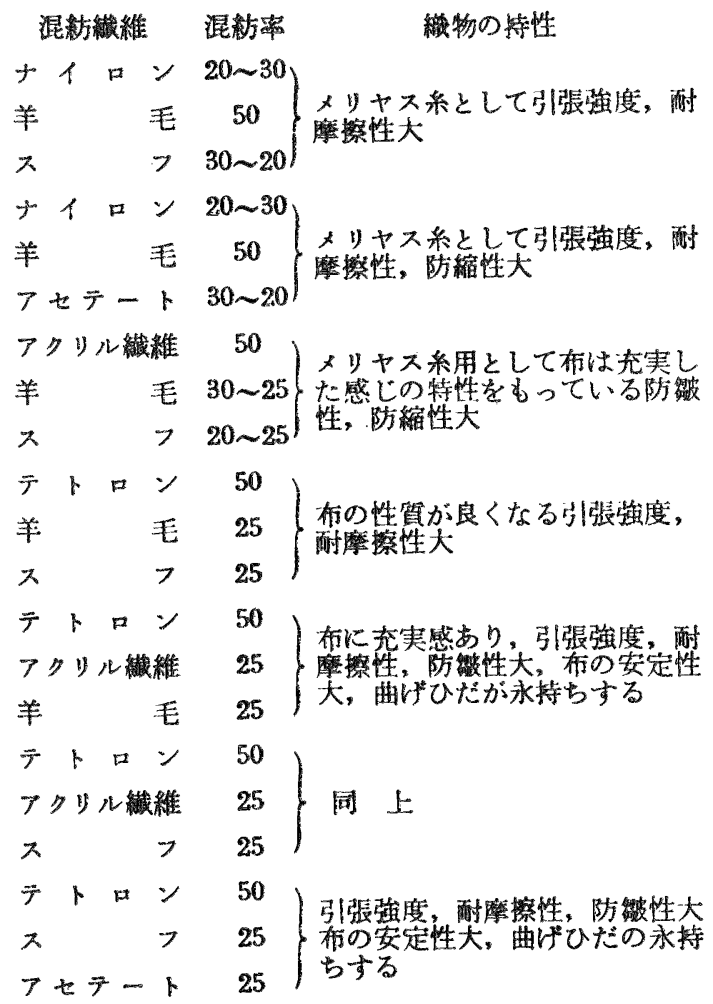

Du. Pont 社は 1950 年より 4 年余にわたり大規模な 混紡研究を行なった。異種の瀻維を単に混紡しただけで は期待通り，その拉のおのの長所を発揮させ，その欠点 を除くことが必らずしも可能でないのみならず，時とし てはむし万欠点となる場合るある。満足な混紡効果を得 るためには，緫維の選択と共に混紡率が適正でなければ なら始ことが明らがされたのである。ての意味で上記

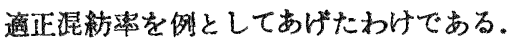

\section{4. 最近の驖維加エ技術}

\section{(1) 原綰の改良}

各瀻維はとれそれれ特有の良い性質を持つ反面衣料とし ての欠点となり得る性筫む有している。この欠点を改度 するため,他瀻維との混絃に上る他，繼維自体の性能の 改良に種々研究が進められている、その二,三の例をあ げると

イ）綿のシフノェチル化

綿のシアノェチル化々樹脂加工の併用加工により従来
の加工より塩素吸着性の減少，抗張力の向上，防铍性の 保持，染色性の向上の研究が行なわれている.

口）スフの膨滛性低下括よび耐フルカリ性向上

スフは膨潤性が非常に大きく耐アルカリ性の不良が农 料瀻維としての大さな欠点である。この改質には原料ハ ルプの品質向上とスフ製造技術の向上によって近き将来 解決されるであるう。

(2) 系の加工技術

化学織維のフイラメント糸, 短瀻維系を入れて織維自 体にちぢれ，よじれあるいは小さいルーブを物理的に与 えることによって羊毛風の非常に葓のある，換言すれば 見撒の比重が非常に小さい系を製造する各種加工技術が 実施されている.その例を二，三あげてみよう。

ナイロンは元来ヤング率が低く瞬間の弾性回復が悪く 䍃維自体べたついた触感を有し衣料用として不向きの感 があったので，種ヶの加工技術によってこれらの欠点を 補ならことができた。加工法の例をあけ゚ると

\section{1) ウーリ加工}

ナイロン等のマルチフイラメント糸に撚りを加光，熟 固定をほどこし，然りを解き，伸びの非常に大きい(300 ～400\%) 回復性伈富む毛状効果のある糸を作る. 繧物 として下着，男子靴下，海水着等が市眅されている。

ロ) パンロソ加工

ナイロンを始めとして熱可塑性合成縺維のマルチフィ ラメント糸を加熱した押込み箱の中に押し込め, 熱硬化 させたもので永久的なちぢれを与光非常に柔軟で嵩のあ る毛状効果の系を作る。編物, 織物等化用いられる。最 近日本でる技術を輸入しナイロンのパンロン加工により セータ類、下着類が作られなかなか好評である。

ウーリ加工，ハシンロン加工製品は短瀻維系使用の製品 と翼なり、ビリングの発生がないため今後 Out-Wear の分野に大きく伸びるだろろ。一方，オーロン，フクリ ラン等の熱可塑性緎維を用いて, 高萿性系の製造技術が 発展して来た。その代表的例としてハイ バルク加工が ある. Pacific Converter の特性を利用してオ一ロン， フクリラン,テトロン等のトウ緎維の $30 \sim 40 \%$ を熱緊 張を与え,これを緊張しない緎維と一緒にして率切部を 通過させ短瀻維比切断して紡績系を作り，非常に蒿高い 性質を与える。編物として婦人セ一タ，男子チョッキ， 織物比む用いられる。.Turbo Stapler System とより高 昔性紡績系す作ることがでさる。

（3）織物の加工技術

1）Wash and Wear 織物は最終用涂に淔結したもの であるから人類の衣生活の上に起きるいろんな要求は織 物の加工技術に対する要求である場合が極めて多い． たこれを逆にい克ばこのような要求によって織物の加工 技術の進步向上が促進されていると見ることもできる。

衣料に望む人類の要望はいろいろあるが，その究極の 


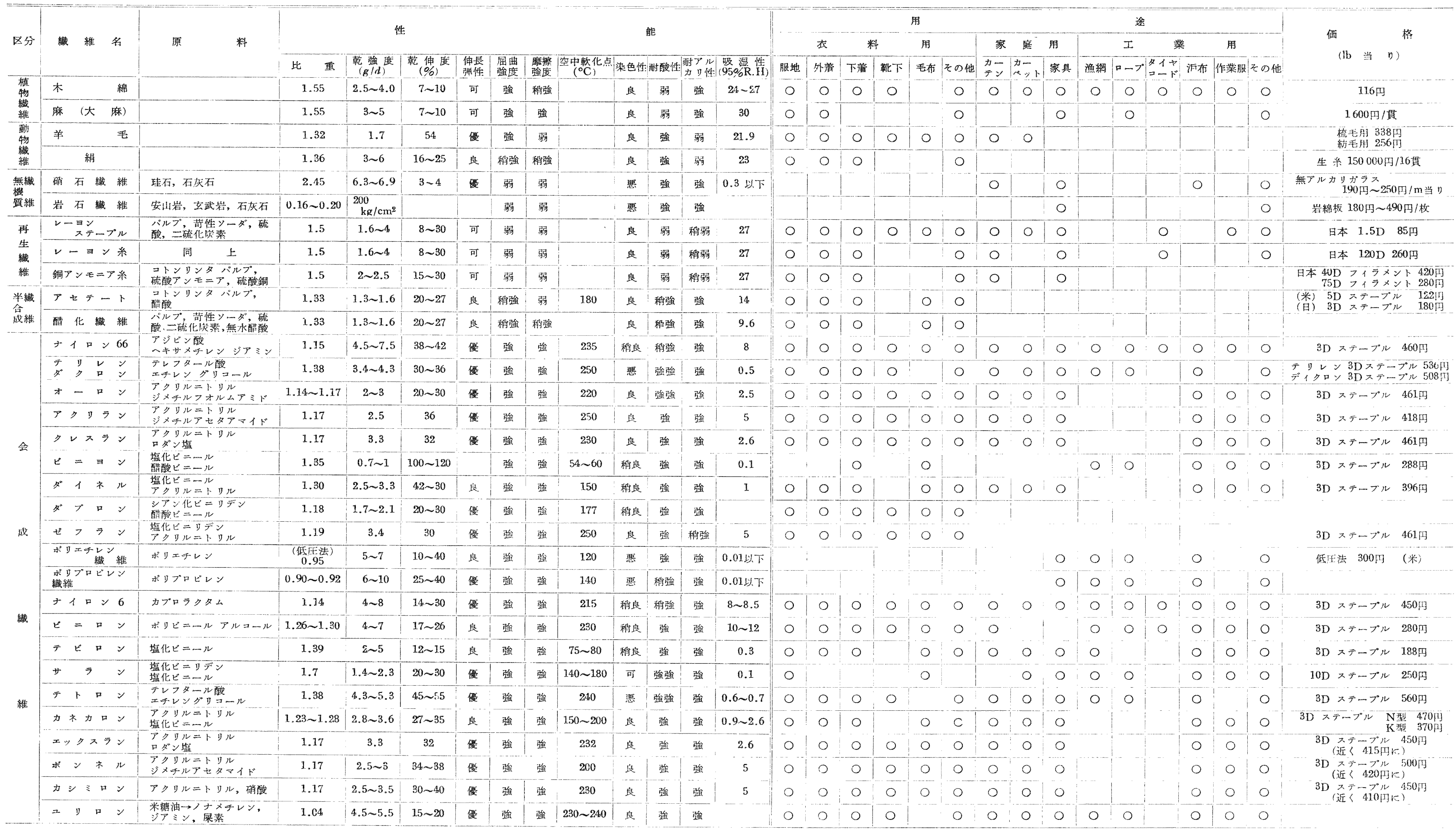

出 所：化瀻協会調，新瀻維総筧，Textile World 
要求を一日Kいえば手数がかからなくて报いやすくいつ までも任立招ろしとの要の状体を保ち，着くずれもせ ず，洗っても形のくずれるないということではなからう か.現在これらの要求を最む近いところむで充たそうし ているのが Wash and Wear とか Easy Care 等の標 示で市貶されている一連の織物である。

織物が Wash and Wear であるための条件は

(1) 触がよりにくいこと

（2）洗った後の乾燥が早く，また洗濯後のアイロン がけ等を要しないこと

（3）洗濯により長さの伸びや縮みのないとと 等である。このためにとるべき手段として樹脂加工をほ どこすことと弾性回復の良い眯水性の合成緎維を混紡す ることが一般に用いられている。前者の手段としては主 として純綿とかスパンレーヨンの織物に対して適用さ れるが，合纖混紡布に対してる樹脂加工をはどこすこと はその Wash and Wear の效果をより一層高める結果 が得られている。

織物に樹脂加工をほどこ好ば樹脂は絲維の非晶領域に 浸透して瀻維と化学的に結合し，㵶維分子間に架橋結合

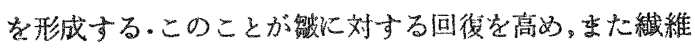
の吸水量を減少させるから乾きが早くなる.合成瀻維を 鼬紡することによって得られる效果むほ洼同様である。

樹脂加工の研究途上汇織物自体との間にもいろいるな 関連性のあることが知られた。例えば織物の強力は樹脂

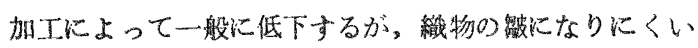

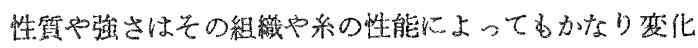
するから，樹脂加工を卧どこす原布は皱になりにくい組 織を選んで加工する樹脂量を少なくするかあるいは同じ 樹脂量で高い防雊性を得るし，また強力口大きい組織や

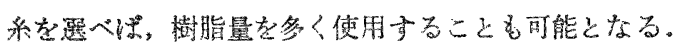
これらのことは樹脂自体の問題および加工方法の閭題と 併行して W ash and Wear を成功させる上の一つの鍵 となっている。るちろん樹脂自体も大い進歩改良され 加工設溥も技術と共に改良された，との詳線はここでは 触れないことにするが，より効果があり，より涌久性の ある樹脂の研究は常に新しい製品を生み出している。

2) その他の技術

Wash and Wear 以外飞。最近発達した技術は多い。 例えば淐来のカルキ漂白は，高能率で高い白度の得られ

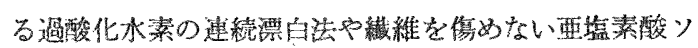
一タ゚に上る漂白法に代りつつあるし，染色に括いて子音 堅案度の高級染料が使用に便利な形で製造され肘壳され ている・これ汇よって染色物は非常に堅牢になり,一般飞 洗ってる変色したり裉色したりすることはなくなった。 しかしこれらのことて要求は一応充たされたのかといら

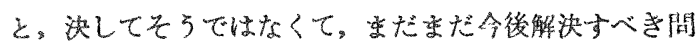
題は山䅡している。研究による解決と新しい要求は常に
循環しながら技術向上させて行く・ズボンたつけた筋 が消えないよ5にという要求をすず解決したのは熱可塑

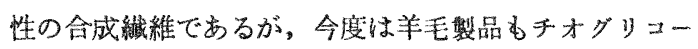
ル酸による羊毛のシスチン結合の阌元切断によって婦人 のコールドパーマと同じ原理で永久的なヒダづけをし よ5とされている。純綿布については研究はされている がまだ解決していないこの他目新しい加工としてはカ ビや細菌の繁殖を防ぐ简生加工や油他水を撜いて活れを つかなくする防污加工等が現在研究発展の段階にある。 これらの研究の完成によって伐料が現在の尖端である。 Wash and Wear ……洗ってすぐ着られる……というこ そからさらに一步前進して洗濯の手数をより省くことに なるであろろ。な緎維素にカルボキシハチル化やシフ ノエチル化等の化学処理を行なって合成瀻維の域以近ず ける研究も行なわれているが，かよう炕天然、合緎を含 めた全緎維が互に競合し，また互にたす计合って，衣料 用として手数のかからない，いつまです仕立特ろしのま まのものに次第に近ずくであろう。

4) 不織布の加工技術

紡績，織布，染色仕上げはここ数年の間に技術の改良 工程の短縮を始め,いろいろ合理化されて来たが，いっ そのこと縄維からすぐ布化ならないかということが誰で る考党られることである。米国で最近発達して来た不織 布がこの夢の契現の第一步である。

不織布とは紡機や織機を使用しないで秏造した瀻維製 品の総称である、米国では Non Woven Fabric，英国で はBonded Fabric と呼ばれている。不織布は繊維が平 行あるいは然秩序に配列されたらすいウェブまたはフェ ルト状のるのが主体になって怙り、これを接着剤で結合 させたりあるいは瀻維の中に低融点, 熱可塑性瀻維を混

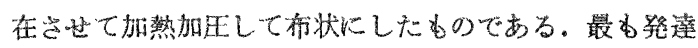
しているの性米国であって1932年他 American Felt Co. 最初の製品が製造されたが，最近急激に增加し，1957年 には 45 工場 9000 万 $\mathrm{lb}, 1$ 億 に迸し, 全布綿生滻量 の1.4\%\%に叔よんている。これらは現在，主として業 用途，家庭の使い唅て分野に使用され衣料分野は恋だ少 ない、例をあげれば (1) 工業用途:フフイルタロス。 座席シ一ト,フェルト, 拭布, レザー、ビニールフィ ルムの襄打も. (2) 家庭用途: ナフォン,タオル,オム

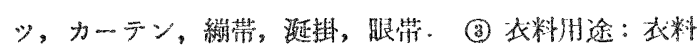
害地, 各種芯地, フレヤスカート。

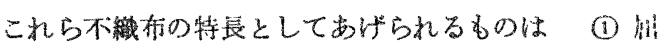
撓性炕富及弹力性がある。(2) 軽く, 道気性があり, し たがって親は涼しく、冬は保温効果がある. (3) 裁断す るとさ活つれない。(4) 安い。

現在日本に执いても数社で生産されつつあり，次第に 一般の珰識が得られるよラになって来て㧍り，今後さら に発展して行くであるう。 